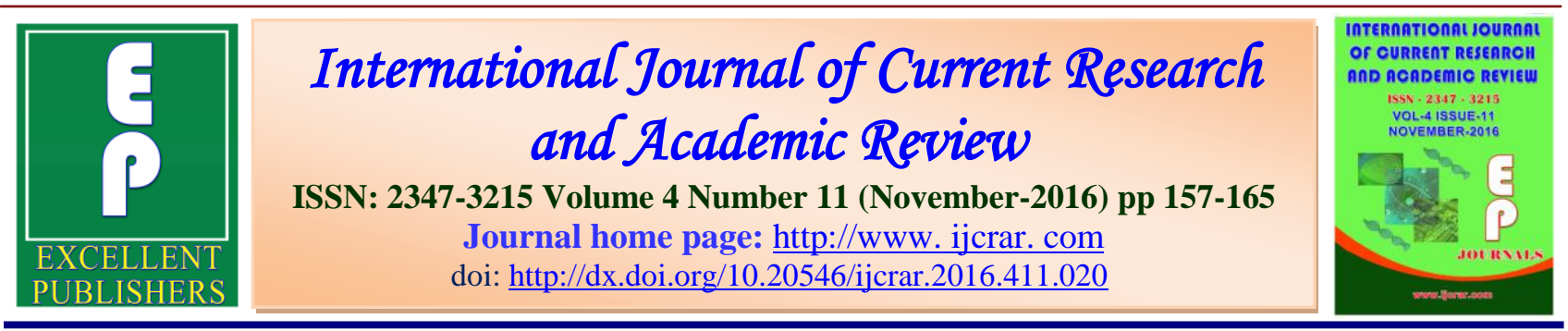

\title{
Assessment of Mental Health in Patients with Hirsutism
}

\section{Ashraf Tashakori ${ }^{1}$, Sorour Nematpour ${ }^{2}$, Hanieh Masih Chegeni ${ }^{3 *}$, Forough Riahi ${ }^{4}$ and Sima Rassai ${ }^{5}$}

${ }^{1}$ Associate Professor, Department of Psychiatry, Golestan hospital, Ahvaz 1Jundishapur University of Medical Sciences, Ahvaz, Iran

${ }^{2}$ Psychiatry Department, School of Medicine, Golestan Hospital, Ahvaz Jundishapur University of Medical Sciences, Ahvaz, Iran

${ }^{3}$ Student Research Committee, Ahvaz Jundishapur University of Medical Sciences, Ahvaz, Iran

${ }^{4}$ Assistant Professor, Department of Psychiatry, Golestan hospital, Ahvaz Jundishapur University of Medical Sciences, Ahvaz, Iran

${ }^{5}$ Department of Dermatology, Ahvaz Jundishapur University of Medical Sciences, Ahvaz, Iran

*Corresponding author

\section{KEYWORDS}

Hirsutism,

Mental health, Demographic characteristics.

\section{A B S T R A C T}

Hirsutism is defined as excessive growth of terminal hair on the face and body of women with male distribution type pattern. In a series of studies, the prevalence of hirsutism has been reported 5-8\% of the total female population. The effect of hirsutism on life quality of women may be profound and may cause mental disorders that threaten female identity. This is an epidemiological-analytical study which was conducted on patients with hirsutism referred to dermatology clinic of Ahvaz Imam Khomeini (RA) hospital as case group and non-hirsute people among the fellows of patients referred to dermatology clinic as control group. 97 patients with hirsutism as case group and 97 non-hirsute people as control group completed the mental health questionnaire (SCL-90-R). To analyze the data, independent $t$ test, chi-square test and Spearman correlation coefficient were used. All analyzes were conducted by using SPSS software version 20. Mental health of patients with hirsutism was significantly lower than the control group. Variables depression, anxiety, physical complaints, obsessioncompulsion, interpersonal sensitivity, phobic anxiety, psychosis and paranoid ideation are more in patients with hirsutism compared to non-hirsute people. There is no a significant relationship between age, marital status, site of hirsutism and family history of hirsutism with mental health in patients with hirsutism. Mental health of patients with hirsutism is lower than the non-hirsute people. So with regard to the effect of hirsutism on mental health of these people and their life quality, they need to psychiatric consultation alongside the treatment of disease which can lead to reduction of mental disorders and getting better of their mental health. 


\section{Introduction}

Hirsutism is a common disorder as excessive growth of terminal hair with male pattern of distribution in women including chin, upper lip, chest, back and abdomen (1). After goiter, hirsutism is the most common cause of women's referral to clinics in the country (2). The hirsutism is different in different societies. For example, a woman in a culture is hirsute and may be quite normal in other culture (3). In a series of studies, the prevalence of hirsutism has been reported 5$8 \%$ of the total female population (4 and 5). There are several reasons in advanced hirsutism; androgenic factors are the most common cause, accounting for almost $80 \%$ of cases to themselves (6). The effect of hirsutism on life quality of women may be profound and may cause mental disorders that threaten female identity (7). In a casecontrol study conducted by Dr. Hajheydari Z et al. in 2007 on 100 hirsute women who referred to dermatology clinic in Sari, Mazandaran, Iran from 2004 to 2005 as case group and 100 non-hirsute women as control group who were matched in terms of demographic characteristics and the SCL90-R questionnaire was used, they came to the conclusion that $43 \%$ of women with hirsutism have mental disorders such as paranoid and depression and $42 \%$ of the control group were susceptible to mental disorders. There was no significant difference between the two case and control groups in terms of mental disorders (8).

In a case-control study conducted by Sonino $\mathrm{N}$ et al. in 1993 on 50 women postmenarche women with hirsutism referred to Semeiotica Medical Clinic of Padova University as case group and 50 non-hirsute women as control group and SRT and SSQ questionnaires were used, they came to the conclusion that women with hirsutism have more psychological disorders and interpersonal concerns compared to the control group. Concerns in women with hirsutism include: dealing with people at work, meeting with strangers, finding friends and going to shopping and partying (9).

In a cross sectional descriptive-analytical study conducted by Sotoudeh et al. in 2007 on 55 women of 16-38 years old with increased levels of serum testosterone and and rostenedione or clinical signs of hirsutism, the mean of overt anxiety was 44 . $25 \%$, covert anxiety $47.25 \%$ and depression 40. $22 \%$, they came to the conclusion that the amount of anxiety and depression in these women is high (10).

In a case report study conducted by Hample $\mathrm{H}$ et al. in 2001 on a female patient with 73 years old with hirsutism and major depression that was under the psychopharmacologic treatment for a period of 6 months, they came to the conclusion that the hirsutism in patients with major depression is greater compared to the control group (11).

In a study conducted by Barth $\mathrm{J}$. $\mathrm{H}$ et al in September 1993 on 69 women with premenopausal hirsutism and used the GHQ questionnaire, they came to the conclusion that almost 1 . 3 of people had never previously talked about their disease and 2 . 3 of them withdrew from some social situations. Psychological disorders are associated with poor social judgment, high levels of neurological disorders, introspection and resignation of some social situations, but it was not associated with the severity of hirsutism or testosterone level (12).

Anxiety and depression in women with hirsutism is more compared with those without hirsutism (13). Hirsutism is a source of particular anxiety in women (14). These 
conditions can cause changes in individual perceptions, impaired family dynamics and work problems (15 and 16).

The disease in adolescents with hirsutism has a negative impact on various aspects of life quality, including limits on physical activities, universal behaviors and congenital activities (17).

Considering the fact that we have found few studies for examining the mental health in women with hirsutism and few studies have been done in Iran in this field and the studies have provided contradictory reports from mental health of women with hirsutism, this study aimed to evaluate the mental health in patients with hirsutism referred to dermatology clinic. According to the above and necessary for more quickly treatments, we attempted to examine the mental health in patients with hirsutism and its relationship to some of their demographic characteristics.

\section{Methodology}

This is an epidemiological-analytical study. In this study, 97 patients with hirsutism referred to dermatology clinic of Ahvaz Imam Khomeini (RA) hospital as case group and97 non-hirsute people among the fellows of patients referred to dermatology clinic as control group were randomly studied with the knowledge of the purpose of the plan and obtaining consent. People with other skin diseases associated with hirsutism who were diagnosed by the clinic dermatologist as well as acute psychosis patients, people with mental retardation, cognitive disorders, psychosis and dementia and illiterate people who are not able to understand and answer the questionnaire are excluded from the study.

The study used the SCL-90-R questionnaire that its validity and reliability have been proven in Iran and 4\% cut-off point has been reported for it. For personal data, the demographic questionnaire including age, marital status, site of hirsutism and family history of hirsutism is used.

SCL-90-R test consists of 90 questions to assess mental symptoms which was introduced by Derogatis, Lipman and Covi (1973) and revised based on clinical assessment and psychometric analysis. Then its final form was prepared (Derogatis, Rickels, Rock, 1976).

90 articles of the test cover 9 aspects of physical complaints, obsession and compulsion, sensitivity in interpersonal relationships, depression, anxiety, hostility, phobic anxiety, paranoid ideation and psychosis. Responses provided to each of the test are answered in a scale of five options from (none) to (strictly). Scoring and interpretation of the test are performed based on Global Severity Index (GSI) symptoms, Positive Symptom Distress Index (PSDI) and Positive Symptom Total (PST).

Derogatis (1983) has conducted the reliability of 9 dimensions with internal reliability and test-retest methods. Also reported that the internal reliability was satisfactory for 9 cases; the highest correlation associated with depression was (0. 90) and the lowest correlation associated with psychosis was (0. 77). Test-retest reliability has been reported 0.78 to 0.90 . Examining 2241 psychiatric patients, addicts and healthy subjects, Mirzayi (1980) has reported that reliability of the test in all scales was more than 0.80 except hostility, phobic anxiety and paranoid ideation. Construct validity obtained shows that this test can be used in Iran as means for diagnosis of mental disorders. The test can be carried out by a nurse, technician or clinical interviewers. The time required to 
perform is about 12 to 15 minutes, but serious persons may complete it in 30 minutes or more. The test evaluates individuals' states from a week ago to the present and this is when the person refers to the time for answering it (18). To describe data, the mean and standard deviation for quantitative variables and frequency and percentage for qualitative variables were used. To analyze the data, independent $t$ test, chi-square and Spearman correlation coefficient were used. All analyzes were conducted by using SPSS software version 20 .

\section{Results and Discussion}

Mental health score has the mean of 175. 47 and standard deviation of 50.71 in group of people with hirsutism and mean of 147. 61 and standard deviation of 28. 87 in the control group. There is a significant relationship (P-value $<0.001$ ).

The variable physical complaints score in group of people with hirsutism is 24.81 and standard deviation is 8.68 and the mean and standard deviation in the control group are 20. 07 and 6.42 respectively. There is a significant relationship (P-value $<0$. 001). The variable obsessive-compulsion score has the mean of 19.17 and standard deviation of 6.31 in hirsutism group and the mean of 16. 46 and standard deviation of 4 . 12 in the control group. There is a significant relationship $(\mathrm{P}$-value $=0.001)$. The variable sensitivity in interpersonal relations score has the mean of 15.11 and standard deviation of 5.27 in group of people with hirsutism and the mean of 13 . 10 and standard deviation of 3. 64 in the control group. There is a significant relationship $(\mathrm{P}$-value $=0.002)$. The variable depression score has the mean of 25.90 and standard deviation of 9.22 in group of people with hirsutism and the mean of 21 .
29 and standard deviation of 5.48 in the control group. As can be seen, there is a significant relationship ( $\mathrm{P}$-value $<0$. 001). The variable anxiety score has the mean of 18. 80 and standard deviation of 6.79 in group of people with hirsutism and the mean of 16.15 and standard deviation of 3.92 in the control group. There is a significant relationship $(\mathrm{P}$-value $=0.001)$.

The variable hostility score has the mean of 11. 67 and standard deviation of 4.15 in group of people with hirsutism and the mean of 9.86 and standard deviation of 2.56 in the control group. There is a significant relationship (P-value $<0.001)$. The variable phobic anxiety score has the mean of 11.94 and standard deviation of 3. 45 in group of people with hirsutism and the mean of 10 . 62 and standard deviation of 2.28 in the control group. There is a significant relationship $(\mathrm{P}$-value $=0.002)$. The variable paranoid ideation score has the mean of 12 . 92 and standard deviation of 4.90 in group of people with hirsutism and the mean of 10 . 77 and standard deviation of 3. 41 in the control group. There is a significant relationship ( $\mathrm{P}$-value $<0.001)$. The variable psychosis score has the mean of 17.97 and standard deviation of 5.57 in group of people with hirsutism and the mean of 15 . 88 and standard deviation of 4.34 in the control group. There is a significant relationship $(\mathrm{P}$-value $=0.004)$.

As can be seen, the mental health scores has no significant relationship according to age variable of correlation coefficient (-0. 08) $(\mathrm{P}$-value $=0.432)$. The mental health has the mean of 185.72 and standard deviation of 59.94 among single people in the group of people with hirsutism and mean of 165 . 42 and standard deviation of 37. 64 in married people. There is no significant relationship $(\mathrm{P}$-value $=0.05)$. 
Mental health score has the mean of 173.75 and standard deviation of 49. 97 in people who have hirsutism above the lip and mean of 192.33 and standard deviation of 57.91 in people who do not have hirsutism above the lip. There is no significant relationship (P-value $=0.297)$.

Mental health score has the mean of 173.28 and standard deviation of 49.68 in people who have chin hirsutism and mean of 183 . 90 and standard deviation of 55. 03 in people who do not have chin hirsutism. There is no significant relationship ( $\mathrm{P}$-value $=0.407$ ).

Mental health score has the mean of 176. 85 and standard deviation of 53. 15 in people who have chest hirsutism and mean of 174 . 12 and standard deviation of 48.71 in people who do not have chest hirsutism. There is no significant relationship (P-value $=0.792$ ).

Mental health has the mean of 197. 85 and standard deviation of 52. 11 in people who have hirsutism in the area below the navel and mean of 169. 23 and standard deviation of 48. 62 in people who do not have hirsutism in the area below the navel. There is no significant relationship $(\mathrm{P}$-value $=0$. 312).

Mental health has the mean of 171.75 and standard deviation of 47.33 in people who have hirsutism on the inner surface of the thigh and mean of 179.77 and standard deviation of 54. 58 in people who do not have hirsutism on the inner surface of the thigh. There is no significant relationship $(\mathrm{P}-$ value $=0.440)$.

Mental health has the mean of 174. 87 and standard deviation of 51. 23 in people who have hirsutism in the lower back area and mean of 175. 28 and standard deviation of 51. 10 in people who do not have hirsutism in the lower back area. There is no significant relationship $(\mathrm{P}$-value $=0.971)$.

Mental health has the mean of 175. 94 and standard deviation of 49.56 in people who have family history of hirsutism and mean of 174. 95 and standard deviation of 52. 50 in people who do not have history of hirsutism. There is no significant relationship $(\mathrm{P}$-value $=0.971)$.

The present study examines the mental health of 97 patients with hirsutism referred to dermatology clinic of Ahvaz Imam Khomeini (RA) hospital as case group and 97 non-hirsute people among the fellows of patients referred to dermatology clinic as control groupand its relationship with some of their demographic characteristics including age, marital status, site of hair growth, and family history of hirsutism.

With respect to the variables age, marital status, site of hair growth in the area of above lip, chin, chest, below the navel, inner thigh and lower back areas and family history of hirsutism, checking the mental health showed that there is no significant relationship between mental health and the mentioned variables. In terms of variables such as age, marital status and site of hair growth, results of this study are consistent with the results of Hajheydari Z study based on the lack of relationship between age and site of hair growth and marital status with mental health in women with hirsutism compared to the control group (8). But it is different from the Sonino $\mathrm{N}$ studies in terms of hair growth variable (9). Appearance changes in patient with hirsutism can cause psychological disorders as well as the impact on female identity (7). A study conducted by Sotoudeh et al. showed that the high levels of overt and covert anxiety, and depression in the lower age groups compared to older people and married 
Int. J. Curr. Res. Aca. Rev. 2016; 4(11): 157-165

women (10). The possible reason could be that this study included only hirsute women with increased levels of blood androgens that women are faced with problems such as infertility with increasing this enzymeand this can cause depression and anxiety in these people. As well as, high levels of androgens can cause depression.

Table.1 Compare the mental health of patients with hirsutism and non-hirsute people

\begin{tabular}{|c|c|c|c|c|c|c|c|}
\hline \multicolumn{8}{|c|}{ Table 1} \\
\hline & \multicolumn{2}{|c|}{ Case group } & \multicolumn{2}{|c|}{ Control group } & t-statistic & $\begin{array}{c}\text { Degrees } \\
\text { of }\end{array}$ & P-value \\
\hline \multirow[t]{2}{*}{$\begin{array}{l}\text { Mental } \\
\text { health }\end{array}$} & Mean & $\begin{array}{r}\text { Standard } \\
\text { deviation }\end{array}$ & Mean & $\begin{array}{l}\text { Standard } \\
\text { deviation }\end{array}$ & \multirow[t]{2}{*}{ 4. 701} & \multirow[t]{2}{*}{152} & \multirow[t]{2}{*}{$<0.001$} \\
\hline & 175.47 & 50.71 & 147.61 & 28.87 & & & \\
\hline
\end{tabular}

Table. 2 Psychological disturbances measured by symptom check list revised (SCL-90-R) in women with hirsutism and control

\begin{tabular}{|c|c|c|c|c|c|c|}
\hline \multicolumn{2}{|c|}{ Variable } & Mean & SD & t statistic & $\begin{array}{l}\text { Degrees of } \\
\text { freedom }\end{array}$ & $P$-value \\
\hline \multirow{2}{*}{$\begin{array}{l}\text { Physical } \\
\text { complaints }\end{array}$} & Case & 24.81 & 8.68 & \multirow[t]{2}{*}{4.319} & \multirow[t]{2}{*}{177} & \multirow[t]{2}{*}{$<0.001$} \\
\hline & Control & 20.07 & 6.42 & & & \\
\hline \multirow{2}{*}{$\begin{array}{l}\text { Obsession- } \\
\text { compulsion }\end{array}$} & Case & 19.17 & 6.31 & \multirow[t]{2}{*}{3.54} & \multirow[t]{2}{*}{171} & \multirow[t]{2}{*}{0.001} \\
\hline & Control & 16.46 & 4.12 & & & \\
\hline \multirow{2}{*}{$\begin{array}{c}\text { Sensitivity in } \\
\text { interpersonal } \\
\text { relations }\end{array}$} & Case & 15.11 & 5.27 & \multirow[b]{2}{*}{3.08} & \multirow[b]{2}{*}{171} & \multirow[b]{2}{*}{0.002} \\
\hline & Control & 13.10 & 3.64 & & & \\
\hline \multirow[t]{2}{*}{ Depression } & Case & 25.90 & 9.22 & \multirow[t]{2}{*}{4.22} & \multirow[t]{2}{*}{156} & \multirow[t]{2}{*}{$<0.001$} \\
\hline & Control & 21.29 & 5.48 & & & \\
\hline \multirow[t]{2}{*}{ Anxiety } & Case & 18.80 & 6.79 & \multirow[t]{2}{*}{3.325} & \multirow[t]{2}{*}{154} & \multirow[t]{2}{*}{0.001} \\
\hline & Control & 16.15 & 3.92 & & & \\
\hline \multirow[t]{2}{*}{ Hostility } & Case & 11.67 & 4.15 & \multirow[t]{2}{*}{3.63} & \multirow[t]{2}{*}{160} & \multirow[t]{2}{*}{$<0.001$} \\
\hline & Control & 9.86 & 2.56 & & & \\
\hline \multirow{2}{*}{ Phobic anxiety } & Case & 11.94 & 3.45 & \multirow{2}{*}{3.14} & \multirow[t]{2}{*}{167} & \multirow{2}{*}{0.002} \\
\hline & Control & 10.62 & 2.28 & & & \\
\hline \multirow{2}{*}{$\begin{array}{l}\text { Paranoid } \\
\text { ideation }\end{array}$} & Case & 12.92 & 4.90 & \multirow[t]{2}{*}{3.549} & \multirow[t]{2}{*}{171} & \multirow[t]{2}{*}{$<0.001$} \\
\hline & Control & 10.77 & 3.41 & & & \\
\hline \multirow[t]{2}{*}{ Psychosis } & Case & 17.97 & 5.57 & \multirow[t]{2}{*}{2.91} & \multirow[t]{2}{*}{192} & 0.004 \\
\hline & Control & 15.88 & 4.34 & & & \\
\hline
\end{tabular}

Table.3 Investigate the relationship between age and mental health in patients with hirsutism

\begin{tabular}{|c|c|c|}
\hline \multicolumn{3}{|c|}{ Table 3 } \\
\hline \multicolumn{3}{|c|}{ Age of patients with hirsutism } \\
\hline & Correlation coefficient & P-value \\
\hline Mental health & -0.08 & 0.432 \\
\hline
\end{tabular}


Int. J. Curr. Res. Aca. Rev. 2016; 4(11): 157-165

Table.4 Relationship between mental health and demographic characteristics of patients with hirsutism

\begin{tabular}{|c|c|c|c|c|c|c|c|}
\hline \multicolumn{2}{|c|}{ Variable } & Frequency & Mean & SD & t statistic & $\begin{array}{l}\text { Degrees of } \\
\text { freedom }\end{array}$ & P-value \\
\hline \multirow[t]{2}{*}{ Marital status } & Single & 48 people & 185.72 & 59.94 & \multirow[t]{2}{*}{1.99} & \multirow[t]{2}{*}{79} & \multirow[t]{2}{*}{0.05} \\
\hline & Married & 49 people & 165.42 & 37.64 & & & \\
\hline \multirow{2}{*}{$\begin{array}{l}\text { Site of hair } \\
\text { growth } \\
\text { (above lip) }\end{array}$} & Have & 88 people & 173.75 & 49.97 & \multirow[b]{2}{*}{1.04} & \multirow[b]{2}{*}{95} & \multirow[b]{2}{*}{0.297} \\
\hline & $\begin{array}{c}\text { Have } \\
\text { no }\end{array}$ & 9 people & 192.33 & 57.91 & & & \\
\hline \multirow{2}{*}{$\begin{array}{l}\text { Site of hair } \\
\text { growth } \\
\text { (Chin) }\end{array}$} & Have & 77 people & 173.28 & 49.68 & \multirow[b]{2}{*}{0.833} & \multirow[b]{2}{*}{95} & \multirow[b]{2}{*}{0.407} \\
\hline & $\begin{array}{l}\text { Have } \\
\text { no }\end{array}$ & 20 people & 90.183 & 55.03 & & & \\
\hline \multirow{2}{*}{$\begin{array}{l}\text { Site of hair } \\
\text { growth } \\
\text { (chest) }\end{array}$} & Have & 48 people & 176.85 & 53.15 & \multirow[b]{2}{*}{-0.264} & \multirow[b]{2}{*}{95} & \multirow[b]{2}{*}{0.792} \\
\hline & $\begin{array}{c}\text { Have } \\
\text { no }\end{array}$ & 49 people & 174.12 & 48.71 & & & \\
\hline \multirow{2}{*}{$\begin{array}{l}\text { Site of hair } \\
\text { growth } \\
\text { (below the } \\
\text { navel) }\end{array}$} & Have & 57 people & 179.85 & 52.11 & \multirow[b]{2}{*}{-1.017} & \multirow[b]{2}{*}{95} & \multirow[b]{2}{*}{0.312} \\
\hline & $\begin{array}{l}\text { Have } \\
\text { no }\end{array}$ & 40 people & 23. 169 & 62.48 & & & \\
\hline \multirow{2}{*}{$\begin{array}{l}\text { Site of hair } \\
\text { growth (inner } \\
\text { thigh area) }\end{array}$} & Have & 52 people & 171.75 & 47.33 & \multirow[b]{2}{*}{0.776} & \multirow[b]{2}{*}{95} & \multirow[b]{2}{*}{0.440} \\
\hline & $\begin{array}{c}\text { Have } \\
\text { no }\end{array}$ & 45 people & 179.77 & 54.58 & & & \\
\hline \multirow{2}{*}{$\begin{array}{l}\text { Site of hair } \\
\text { growth } \\
\text { (lower back) }\end{array}$} & Have & 32 people & 174.87 & 51.23 & \multirow[b]{2}{*}{0.037} & \multirow[b]{2}{*}{94} & \multirow[b]{2}{*}{0.971} \\
\hline & $\begin{array}{c}\text { Have } \\
\text { no }\end{array}$ & 64 people & 175.28 & 51.10 & & & \\
\hline \multirow{2}{*}{$\begin{array}{c}\text { Family } \\
\text { history of } \\
\text { hirsutism }\end{array}$} & Have & 51 people & 175.94 & 49.56 & \multirow[b]{2}{*}{0.095} & \multirow[b]{2}{*}{95} & \multirow[b]{2}{*}{0.925} \\
\hline & $\begin{array}{l}\text { Have } \\
\text { no }\end{array}$ & 46 people & 174.95 & 52.50 & & & \\
\hline
\end{tabular}

Considering the variables of depression and paranoid ideation, checking out the mental health scores showed that depression and paranoid ideation are greater in patients with hirsutism compared with non-infected ones. These findings are consistent with results of Hample $\mathrm{H}$ study based on high major depression in patients with hirsutism (11). The results of this study are consistent with the results Hajheydari $Z$ study based on high level of depression and paranoid ideation in patients with hirsutism (8).

The present study indicates that the mental health score in patients with hirsutism is more compared to healthy subjects in terms of anxiety variable. The results of this study are consistent with the study results of Dr. Sotoudeh et al. (10).

In terms of sensitivity in interpersonal relations variable, checking the mental health scores shows that sensitivity in interpersonal relations in patients with hirsutism is morethan the one in healthy people which is consistent with results of Sonino $\mathrm{N}$ indicating that women with hirsutism showed more psychological disorders and interpersonal concerns than the control group. Concerns in women with hirsutism include mixing with people at work, meeting with strangers, finding 
friends and going shopping and partying (9). In suffered adult women, hirsutism can have different effects on quality of life, including limitations on physical activities, general behavior and family activities (7).

Results of the present study show that mental health in patients with hirsutism is more compared to the control group considering the variables of psychosis, phobic anxiety and hostility and physical complaints and obsession-compulsion.

The mean and standard deviation of mental health in patients with hirsutism compared to healthy subjects are statistically significant that the results of this study are different from the Hajheydari, study (8) and are not consistent with studies of Fava et al. (19). Therefore due to low mental health of patients with hirsutism compared with the control group, it is suggested based on this study that steps to be takenby investigating and taking into account the medical support measures of psychiatry and psychology to improve mental health and life quality improvement of patients with hirsutism as part of this study, and necessary trainings in the field of mental disorders of patients with hirsutism be given to health care workers to take action about the identification and following up the psychological problems of patients with hirsutism.

The present study showed an appropriate estimation from mental health status of patients with hirsutism compared with healthy people, but there were some limitations. One of these limitations is whether the patients have realistic answer to the questions and that patients have been under what conditions in terms of physical and mental status at the time of completing the questionnaire and this may also affect the way of their responding. Another limitation is that this study was conducted on a small sample size. Carrying out studies on larger sample size could give us more accurate information. Mental health questionnaire was only used in this study and Quality of Life Questionnaire can be used for detailed examination of life quality of these people, given that hirsutism can affect the quality of people's lives.

\section{References}

1.Gacaferri Lumezi B, Goci A, Lokaj V, Latifi H, Karahoda N, Minci G, Telaku D, Gercari A, Kocinaj A. Mixed Form for Hirsutism in an Adolescent Female and Laser Therapy. Iran Red Crescent Med J; 16(6):e9410

2.Qadri Raza, Ghulam Sharif-Zadeh Reza. cross-border, cross-border Rehana. Relationship between hirsutism and levels of sex hormones. Journal of Birjand University of Medical Sciences. 1383; 11 (3): 11-17

3.Sherins R J, Horton R. Hirsutism and virilization/ Calif Med. 1967 Feb; 106(2):87-91

4.Hunter M H, Carek P J. Evaluation and treatment of women with hirsutism. Am Fam psychician 2003;67:25652572.

5.Rosenfield, $\mathrm{R}$ L. Clinicalpractice. Hirsutism. N Engle J Med 2005; 352:2578-25885

6.RamotY, Sheffer S, Zlotogorski A. Sever facial Hirsutism Following Isotretinoin Therapy: An Under-reported Entity. Int. J Trichology. 2015 Jul Sep;7(3):129-130

7.Keegan A, Liao LM, Boyle M. Hirsutism :a psychological analysis. J Health psycho 2003;8:327-345

8.Hajheydari Z, Jamshidi M, Masoudzadeh A. Association between hirsutism and mental health. Neurosciences 2007; vol 12(3):242-244. 
Int. J. Curr. Res. Aca. Rev. 2016; 4(11): 157-165

9. Sonino N, Fava GA, Mani E, Belluardo P, Boscaro J1993;69:186-189

10.Sotude Giti, Siasi Fereydun, Lesan Shirin, Mirdamadi Syed Rehan, Chmry Mary. Prevalence of anxiety and depression and related factors in women with elevated androgen levels Khvn. mjlh of Medical Council of Islamic Republic of Iran, Volume 25, Number 4, Winter 1386: 489-482

11.Hample H, Kotter HU, Padberg F, Berger C. Sever hirsutism associated with psychopharmacological treatment in major depression. World $\mathrm{J}$ Biol Psychiatry2001;2:48-49

12.BarthJH, Catalan J, Cherry C. A, Day A. Psychological morbidity in women referred for treatment of hirsutism $\mathrm{J}$ Psychosom Res 1993;37:615-619

13.PalmentunEkback M, Lindberg M, Benzein E, Arestedt K. Social support : an important factor for quality of life in women with hirsutism. Health Qual Life Outcome. 2014; 12: 183

14.Hohl A, Ronsoni MF, Oliveira Md. Hirsutism : diagnosis and treatment. Arq Bras EndocrinolMetabol. 2014 Mar; 58(2): :97-107
15.Harison S, Somani N, Bergfeld WF. Update on the management of hirsutism. Cleve Clin J Med. 2010 Jun; 77(6):388-98. doi : 10. 3949\77a. 08079

16.Paulson JD, Haarman BS, Salerno RI, Asmar P. An investigation of relationship between emotion maladjustment and infertility. Fertile. steril 1988;49:258-262

17.Downey J, Yingling S, Mckinney M, Husami N, Jewelewicz R, Maidman J. Mood disorders, psychiatric symptoms and distress in women presenting for infertility evaluation. Fertilesteril 1989;52:425-432

18.Akha, Rabiei Kh, KashiZ,et al. The effect of fennel (Foeniculum vulgare) gel $3 \%$ in decreasing hair thickness in idiopathic mild to moderate hirsutism, A randomized placebo controlled clinical trial. Caspian J Intel Med. 2014 Winter;5(1):2

19.Fava GA, Grandi S, Savron G, Bartolucci G, Santarsiero G, Trombini G, et al. Psychosomatic assessment of hirsute women. Psychother Psychosom 1989; 51: $96-100$

\section{How to cite this article:}

Ashraf Tashakori, Sorour Nematpour, Hanieh Masih Chegeni, Forough Riahi and Sima Rassai. 2016. Assessment of Mental Health in Patients with Hirsutism. Int. J. Curr. Res. Aca. Rev. 4(12): 157-165. doi: http://dx.doi.org/10.20546/ijcrar.2016.412.020 